КУЛЬТУРА ПРОФЕСІЙНОЇ КОМУНІКАЦІЇ ЯК СКЛАДНИК ПРОФЕСІЙНОї КОМПЕТЕНТНОСТІ МАЙБУТНІХ ЕКОНОМІСТІВ

\title{
CULTURE OF PROFESSIONAL COMMUNICATION AS A COMPONENT OF PROFESSIONAL COMPETENCE OF FUTURE ECONOMISTS
}

\begin{abstract}
Статтю присвячено розкриттю інноваційних аспектів організації самостійної роботи студентів як одного зі шляхів формування культури профресійної комунікації майбутніх фрахівців. У країнах із розвинутими освітніми системами становлення та розвиток профресійної культури фрахівця пов'язують із формуванням комунікативної культури, яка відображає не лише досконале володіння мовою на вербальному й невербальному рівнях, а й здатність спілкуватися, дотримуючись певних морально-етичних норм, 3 урахуванням психологічних особливостей співрозмовника. 3 огляду на це культуру професійної комунікації доцільно розглядати як один з головних компонентів професійноі культури фрахівців.

Інноваційні аспекти організації самостійної роботи студента включають таке: зміну спрямованості педагогічних цілей на саморозвиток і продуктивну самореалізацію особистості студента; спільне (викладачем і студентом) визначення цілей і змісту самостійної роботи студента з опорою на пізнавальний стиль й індивідуальні особливості студента; зміну спрямованості самостійно діяльності на інтелектуальну автономність студента з орієнтацією на активно сконструйоване знання, пов'язану з власними інтересами того, хто навчається, отриманими раніше знаннями, наявним досвідом; зміну у відборі змісту з використанням альтернативних джерел інформачії, в тому числі іноземною мовою, з опорою на міжпредметну інтеграцію знань і особистісний досвід студентів; створення інновачійних надпредметних навчальних програм, стратегій активного навчання, ефективних прийомів і методів роботи з інорормачією; вміння критично оцінювати інфрормаційну цінність альтернативних джерел інформації; зміну методичного забезпечення самостійної роботи; використання інфрормаційних технологій як засобу підтримки самостійної роботи студентів; обов'язкове використання з самого початку навчання творчих форм самостійної роботи; розрахунок трудомісткості самостійної роботи. Ключові слова: самостійна робота студентів, вища просресійна освіта, культура професійної комунікації, інноваційні технології.
\end{abstract}

The article is devoted to the disclosure of innovative aspects of organizing students' independent work as one of the ways of forming the culture of professional communication of future specialists. In countries with advanced educational systems, the formation and development of professional professional culture is associated primarily with the formation of a communicative culture that reflects not only perfect command of the language at the verbal and non-verbal levels, but also the ability to communicate, following certain moral and ethical norms with regard to psychologists . In view of this, the culture of professional communication should be considered as one of the main components of the professional culture of professionals.

Innovative aspects of student self-organization include: changing the focus of pedagogical goals on self-development and productive selfrealization of the student's personality; joint (teacher and student) determination of the goals and content of the student's independent work, with emphasis on cognitive style and individual characteristics of the student; changing the focus of self-activity on the intellectual autonomy of the student with a focus on "actively constructed knowledge" associated with the student's own interests, previously acquired knowledge, experience; changes in content selection using alternative sources of information, including foreign language, with emphasis on cross-curricular integration of knowledge and personal experience of students; creation of innovative curriculum, active learning strategies, effective techniques and methods of working with information; ability to critically evaluate the informational value of alternative sources of information; change of methodical support of independent work; use of information technologies as a means of supporting students' independent work; compulsory use from the very beginning of learning creative forms of independent work; calculation of the complexity of independent work.

Key words: independent work of students, higher vocational education, culture of professional communication, innovative technologies.
Постановка проблеми в загальному вигляді. Головною метою вищої профресійної освіти $€$ підготовка конкурентоспроможного, компетентного фрахівця та створення умов для його профресійного розвитку в процесі навчання. Найважливішою вимогою до університету є забезпечення професійної компетентності випускника. Майбутній фахівець повинен не просто знати, а й вміти розпоряджатися цими знаннями, тобто бути професіоналом, який володіє критичним мисленням, здатністю серед безлічі рішень вибирати найбільш оптимальні, готовим до самоосвіти, самовизначення, саморозвитку.
У сучасному суспільстві, де спостерігаються тенденції віртуалізації усіх сорер життєдіяльності людини, науковці відзначають важливість якісної комунікації в соціумі, що актуалізує проблему фрормування у особи культури комунікації як особистісної, так і профресійної.

Концептуальні засади розвитку культури професійної комунікації ґрунтуються на положеннях міжнародних (Меморандум освіти протягом життя (2000р.), Загальноєвропейські рекомендації 3 мовної освіти (2003р.)) та загальнодержавних документів (закони України «Про освіту» (2017р.), 
«Про вищу освіту» (2014р.), Указ Президента України «Про невідкладні заходи щодо зміцнення державного статусу української мови та сприяння створенню єдиного культурного простору України» (2018 р.), Національна стратегія розвитку освіти в Україні на 2012-2021 роки, Концепція освіти дорослих в Україні (2011р.), Закон «Про професійний розвиток працівників» (2012 р.)).

У країнах із розвинутими освітніми системами становлення та розвиток просресійної культури фрахівця пов'язують із формуванням комунікативної культури, яка відображає не лише досконале володіння мовою на вербальному й невербальному рівнях, а й здатність спілкуватися, дотримуючись певних морально-етичних норм, з урахуванням психологічних особливостей співрозмовника. У багатьох економічно розвинених країнах її вважають головною умовою працевлаштування та кар'єрного зростання у сорері бізнесу, на ринку послуг, у промисловості, управлінні, освіті. 3 огляду на це культуру професійної комунікації доцільно розглядати як один з головних компонентів профресійної культури фрахівців.

Аналіз останніх досліджень і публікацій. Аналіз літератури 3 досліджуваної проблеми свідчить, що професійно-термінологічна компетентність майбутніх бакалаврів економіки не була ще предметом спеціального дослідження, не мала всебічного наукового висвітлення, а розглядалася лише фррагментарно. При цьому акцент робився на окремих аспектах (комунікативному, лінгвістичному, психологічному). Проблеми фрормування професійно-термінологічної компетентності досліджували М. Бахтін (проблеми комунікації), О. Васічкіна, І. Куламіхіна (технології розвитку комунікативної компетентності економістів), Л. Гнатик (організаційно-методичні умови формування комунікативної компетентності майбутніх економістів), Т. Ганніченко (фрормування комунікативної компетенції майбутніх економістів засобами дидактичної гри у процесі мовної освіти), Г. Онуфрієнко (проблема професійної мови й формування мовно-профресійної компетентності майбутніх фрахівців з економіки), В. Приходько (економічна культура), В. Черевко (комунікативна компетентність майбутнього менеджера). Проте виникла потреба розробити та обґрунтувати модель фрормування культури професійної комунікації майбутніх фрахівців з економіки у ЗВО під час вивчення фрахових дисциплін з опорою на цифрові технології.

Виділення не вирішених раніше частин загальної проблеми. В умовах докорінних змін, що відбуваються в системі вищої освіти, різко зростає роль і значення самостійної роботи студентів, яка поступово перетворюється на провідну форму організації навчального процесу. Самостійна робота студентів - один 3 найважливіших елементів навчального процесу. Вироблення у студентів навичок самоосвіти є головним завданням викладача.

Процес комунікації охоплює не тільки обмін інформацією, а й сприйняття та розуміння інших учасників комунікативного процесу і на цій основі вироблення єдиної лінії комунікативної взаємодії. Проте, володіючи лише нормами літературної мови, майбутній фахівець, наприклад, у галузі економіки, не досягне бажаних результатів співпраці, адже в процесі переговорів йому часто доведеться чути специорічні для економіки терміни (дефляяія, ревальвація, операційний важіль, калькуляція тощо), а іноді й сленг (платіжка, кредиторка, дебеторка тощо).

3 огляду на підвищені вимоги сучасного ринку праці до економістів, що зумовлені рівнем розвитку науково-технічного прогресу, рівнем економічного розвитку країни, темпами інфляції, рівнем конкуренції, політичною нестабільністю та соціальнокультурними фракторами, особливого значення набуває культура профресійної комунікації (КПК) фрахівця 3 економіки як складова частина його загальної профресійної культури.

Мета статті - розкрити інноваційні аспекти організації формування культури профресійної комунікації майбутніх фрахівців з економіки.

Виклад основного матеріалу. Культура профресійної комунікації - це така інтегративна якість майбутніх фрахівців з економіки, що охоплює собою комплекс загальних та професійних знань і вмінь, необхідних економісту для організації та здійснення ефективної професійної комунікативної діяльності, та виявляється у позитивному особистісному ставленні до мовленнєвої діяльності й досконалому володінні нормами літературної мови і мовлення, вмінні їх правильного, точного, виразного, комунікативно доцільного застосування у процесі передачі своєї думки у фаховому писемному та усному спілкуванні.

Процес фрормування культури професійної комунікації майбутнього економіста зумовлений фрормуванням таких її складових частин: аксіологічної (тобто ціннісних установок та мотивів професійної комунікації, інтеріоризації загальнокультурних, національних, мовних, професійних цінностей суспільства в особистісні); теоретичної (уявлень про систему мови та знань правил мови і мовлення); мовленнєвої (умінь користуватися економічною термінолексикою, економічною мовою у професійних цілях та для розуміння мовлення інших); комунікативної (здатності користуватися мовою як засобом спілкування у різних професійних ситуаціях); особистісної (здатності до рефрлексії профресійної комунікації).

Модель фрормування культури профресійної комунікації майбутніх фрахівців з економіки в умовах інфрормаційно-освітнього середовища ЗВО 
(рис. 1) має ґрунтуватися на сутності френомену «культура профресійної комунікації майбутніх фрахівців з економіки» і передбачати як результат сорормованість такої культури засобами інфрормаційно-освітнього середовища 3ВО, використовувати поширені та інноваційні фрорми (проблемні лекції, семінари, круглі столи, дискусії, проєкти, конфреренції, web-квести, online-навчання, олімпіади, конкурси, майстер-класи, портороліо, тренінги, вебінари, чати) і методи (проблемні, інтерактивні, ділові ігри, есе, сенкани, роботу зі словниками, діяльність у парах і групах, хмари слів, скрайбінг, дискусії, пошукову діяльність), засоби (мовленнєві, електронні скриньки, соціальні мережі, відеохостинги, навчальні платформи, відео- й аудіозаписи, презентації і проєкти, створення власних професійних вебсайтів, кабінетів і блогів) навчання.

Формування культури профресійної комунікації орахівців з економіки має спиратися на профресіограму економіста, яка з позиції ділової комунікації повинна містити інформацію про комплекс загальних та профресійних знань і вмінь, необхідних фрахівцю для здійснення ефрективної комунікативної діяльності як невід'ємного елемента його профресійної діяльності.

Майбутній економіст повинен володіти:

- літературною українською мовою (повинен застосовувати її фрункціональні можливості);

- економічною термінолексикою та мистецтвом її використання в процесі профресійного спілкування;

- нормами мовного спілкування та його фрормами за способом взаємодії між комунікантами;

- стандартизованими нормами мовленнєвої поведінки у процесі проведення переговорів чи встановлення контакту зі співрозмовниками (для підтримання спілкування у певній тональності), мовленнєвим етикетом;

- вміннями розуміти та реагувати на сказане співрозмовником у професійних ситуаціях спілкування;

- вміннями прогнозувати розвиток діалогу та реакцію співрозмовника;

- вміннями спрямовувати діалог, ураховуючи цілі професійної діяльності.

Концепція дослідження охоплює методологічний, теоретичний і практичний концепти.

Методологічний концепт фрормування культури профресійної комунікації майбутніх фрахівців 3 економіки відображає взаємний зв'язок і взаємодію різних наукових підходів, серед яких провідними виступають системний, андрагогічний, екзистенційний, особистісно-професійний, діяльнісний, акмеологічний, технологічний, аксіологічний, та специфічних принципів цифрровізації освітнього процесу (когнітивності, пізнавальної активності, профресійно орієнтованої комунікації).
Теоретичний концепт містить такі положення:

- культуру профресійної комунікації;

- процес орормування культури просресійної комунікації майбутнього економіста, що зумовлений формуванням таких їі складових частин: аксіологічної (ціннісних установок та мотивів професійної комунікації, інтеріоризації загальнокультурних, національних, мовних, профресійних цінностей суспільства в особистісні); теоретичної (уявлень про систему мови та знань правил мови і мовлення); мовленнєвої (умінь користуватися економічною термінолексикою, економічною мовою у профресійних цілях та для розуміння мовлення інших); комунікативної (здатності користуватися мовою як засобом спілкування у різних профресійних ситуаціях); особистісної (здатності до рефлексії профресійної комунікації);

- модель фрормування культури професійної комунікації майбутніх фрахівців з економіки в умовах інорормаційно-освітнього середовища 3ВО, яка має ґрунтуватися на сутності френомену «культура профресійної комунікації майбутніх фрахівців з економіки» і передбачати як результат сорормованість такої культури засобами інфрормаційно-освітнього середовища 3ВО, використовувати поширені та інноваційні форми, методи, засоби навчання;

- ефрективність моделі фрормування культури профресійної комунікації майбутніх фрахівців з економіки в умовах інфрормаційно-освітнього середовища ЗВО, яка визначається якісними змінами за кожним із показників сорормованості культури професійної комунікації.

Отже, фрормування культури профресійної комунікації майбутніх фрахівців з економіки має відбуватися цілеспрямовано у спеціально створеному у ЗВО інфрормаційно-освітньому середовищі, де передбачено інтеграцію мовної, мовленнєвої, комунікативної і професійної підготовки майбутніх фрахівців з економіки на засадах відкритості, студентоцентризму та циорровізації освітнього процесу.

Висновки. Якщо говорити про сучасний ринок праці, то від випускника ЗВО він вимагає вміння використовувати набуті теоретичні знання в нестандартних ситуаціях і ситуаціях, що постійно зазнають змін. Здійснюється своєрідний перехід від суспільства, в якому віддають перевагу знанням, до суспільства, яке складається 3 життєво компетентних громадян. Як показало дослідження, професійну підготовку майбутніх економістів необхідно розглядати саме через призму компетентнісного підходу, враховуючи ті вимоги, котрі висуває ринок праці до підготовки майбутніх кваліфікованих працівників. Розглядаючи професійну компетентність економіста, ми вважаємо доцільним її доповнити визначення високим рівнем розвитку комунікативних здібностей, наявністю організаторських та управлінських якостей, стійкою 


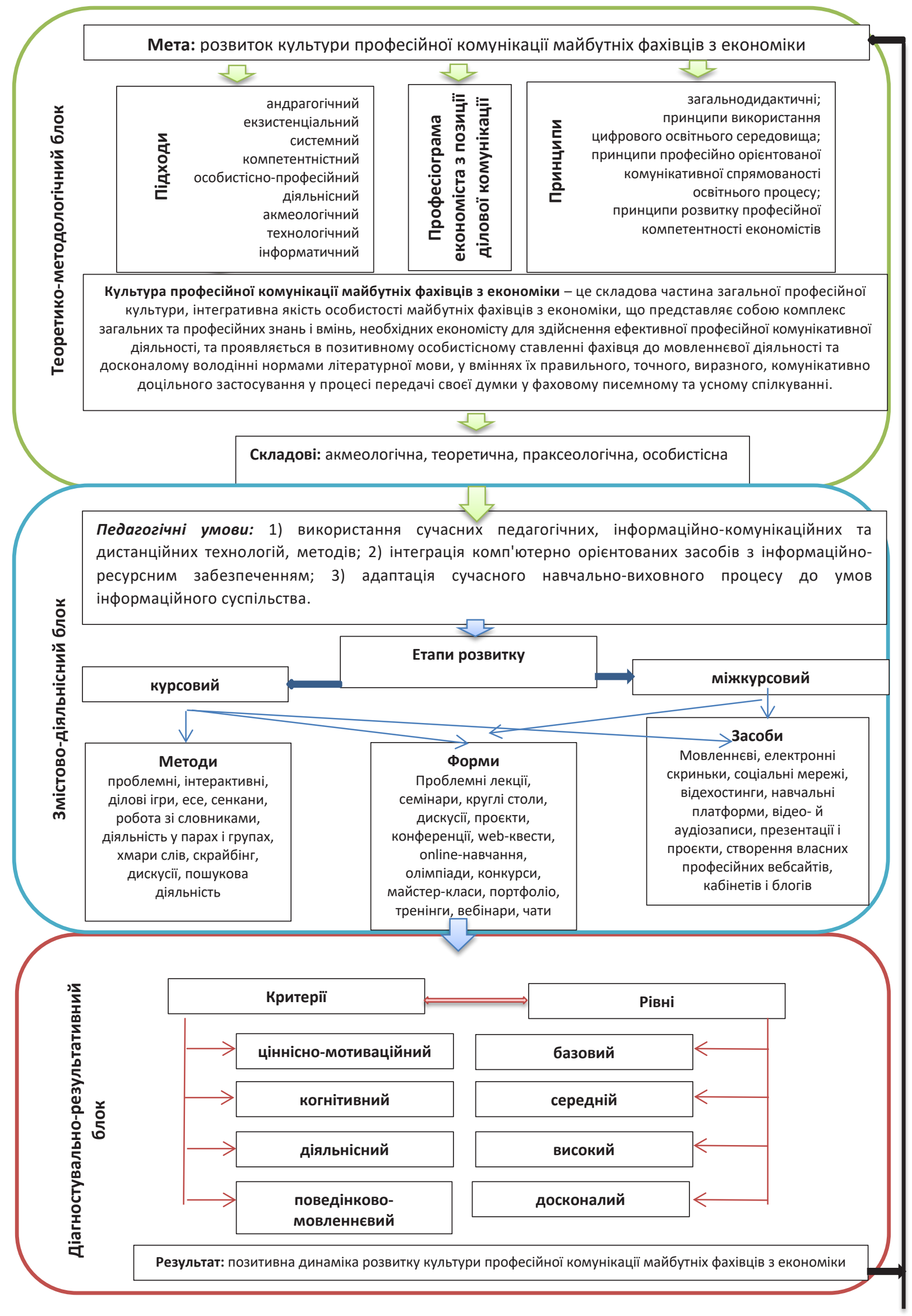

Рис. 1. Модель розвитку культури професійної комунікації майбутніх фахівців з економіки в умовах інформаційно-освітнього середовища 3ВО 
вмотивованістю та володінням інтегрованими знаннями, зокрема щодо використання інформаційно-комунікаційних технологій.

Подальшого дослідження потребують питання необхідності включення в навчальні плани підготовки фрахівців предмета «Комунікативна культура». Потрібний цілеспрямований розгляд питань формування культури профресійної комунікації майбутніх фрахівців в умовах інформаційно-освітнього середовища ЗВО.

\section{БІБЛІОГРАФІЧНИЙ СПИСОК:}

1. Харченко І.І. Формування культури публіцистичного мовлення в студентів. Науковий вісник Херсонського державного університету. Серія «Лінгвістика». Херсон, 2013. Випуск 17. С. 259-263.

2. Харченко И.И. Формирование коммуникативной компетентности студентов аграрного вуза инновационными средствами. Сборник научных трудов «Инновации в науке». Часть II. Новосибирск : Изд. «СибАК», 2013. С. 53-59. 